\title{
Syntheses, characterizations and thermal analyses of four novel unsymmetrical $\beta$-diketiminates
}

\author{
Siddappa A Patil', Phillip A Medina', Joseph W Ziller ${ }^{2}$ and Bradley D Fahlman*
}

\begin{abstract}
Four novel unsymmetrical $\beta$-diketiminates 2-(2,6-diisopropylphenyl)amino-4-(phenyl)imino-2-pentene (4a), 2-(2,6-diisopropylphenyl)amino-4-(4-methylphenyl)imino-2-pentene (4b), 2-(2,6-diisopropylphenyl)amino-4(4-methoxyphenyl)imino-2-pentene (4c) and 2-(2,6-diisopropylphenyl)amino-4-(4-chlorophenyl)imino-2-pentene (4d) were synthesized with a $77-84 \%$ yield, and were characterized by spectroscopic methods ( ${ }^{1} \mathrm{H} \mathrm{NMR},{ }^{13} \mathrm{C} N \mathrm{NMR}$, IR and mass spectrometry), elemental analysis, and X-ray single-crystal diffraction, respectively. Spectroscopic and X-ray single-crystal diffraction analyses determined the structures of the four $\beta$-diketiminates. While thermogravimetric analysis (TGA) and differential scanning calorimetry (DSC) showed two distinct endothermic peaks for each $\beta$-diketiminate at temperatures of $92.55^{\circ} \mathrm{C}$ and $221.50^{\circ} \mathrm{C}(4 \mathrm{a}), 93.51^{\circ} \mathrm{C}$ and $238.82^{\circ} \mathrm{C}(4 \mathrm{~b}), 109.60^{\circ} \mathrm{C}$ and $329.22^{\circ} \mathrm{C}(4 \mathrm{C})$, $115.43^{\circ} \mathrm{C}$ and $243.25^{\circ} \mathrm{C}(4 \mathrm{~d})$, respectively, corresponding to their melting and boiling points.
\end{abstract}

Keywords: Unsymmetrical $\beta$-diketiminate, Synthesis, Spectroscopic investigation, X-ray structure, Thermogravimetric analysis

\section{Background}

The $\beta$-diketiminate class, generally denoted as "nacnac", or $\left[\{\operatorname{ArNC}(\mathrm{R})\}_{2} \mathrm{CH}\right]-$ (where $\mathrm{Ar}=$ aryl and $\mathrm{R}=\mathrm{Me}$ or another group), occupies a rightful place alongside a narrow list of popular ancillary supports, given its ability to stabilize or generate unique coordination environments and to support reactive organometallic reagents or catalysts (Bourget-Merle et al. 2002; Holland 2008; Mindiola 2006; Cramer and Tolman 2007; Roesky et al. 2004; Piers and Emslie 2002; Rahim et al. 1998). The "nacnac" ligand skeleton is analogous to the "acac" (acetylacetonate) ligand, but the oxygen atoms are exchanged for nitrogen-based moieties such as NR ( $\mathrm{R}=$ alkyl, silyl, Ar) (Scheme 1). As a result, the substituent at the nitrogen donor atom can allow for steric protection at the metal center unlike "acac" could offer. When small moieties such as $\mathrm{H}, \mathrm{Me}$, or the $\mathrm{SiMe}_{3}$ on the nitrogen the substance easily forms dimers and allows higher coordination to the metal center, whereas bulky aryl groups on nitrogen usually lead to the isolation of monomeric species with low coordination numbers at the metal.

\footnotetext{
* Correspondence: fahlm1b@cmich.edu

'Department of Chemistry \& Science of Advanced Materials Program, Central Michigan University, Mount Pleasant, MI 48859, USA

Full list of author information is available at the end of the article
}

The first documented cases of $\beta$-diketiminate metal complexes were reported by McGeachin (McGeachin 1968), Parks, and Holm (Parks, and Holm 1968) in 1968. The explosion in popularity of "nacnac" amongst synthetic chemists is driven, in part, by the monoanionic nature of the $\beta$-diketiminate group, the chelating nature but also variable mode of hapticity, the ease in preparation, and the versatility to tune both electronic and steric parameters. Till to date the N-aryl substituted "nacnac" ligands [HN(Ar)C(Me)CHC(Me)N(Ar)] (Nagendran and Roesky $2008)$ and $[\mathrm{HN}(\mathrm{Ar}) \mathrm{C}(t \mathrm{Bu}) \mathrm{CHC}(t \mathrm{Bu}) \mathrm{N}(\mathrm{Ar})]$ (Pfirrmann et al. 2009; Ding et al. 2009) $\left(\mathrm{Ar}=2,6-i \mathrm{Pr}_{2} \mathrm{C}_{6} \mathrm{H}_{3}\right)$ showed to be the best for stabilization of low coordinate metal sites.

The major breakthrough in this area was achieved in the mid 1990's, when $\beta$-diketiminates were used as spectator ligands, thus offering strong metal-ligand bonds like cyclopentadienyls (Scheme 1). In contrast to the latter, $\beta$ diketiminates offer a possibility of subtle tuning of their electronic and steric properties by simple variation of the substituents on nitrogen and adjacent carbon atoms.

The availability of straightforward, multigram syntheses for many classes of $\beta$-diketiminates has generated widespread popularity of the ligand for coordination and organometallic chemistry. Prototypical symmetrical $\beta$ - 
<smiles>CC(=O)C=C(C)C(C)=O</smiles>

(a)<smiles>[R]C(=CC([R])=N[Al])N[Al]</smiles>

(b)<smiles></smiles>

(c)
Scheme 1 Schematic diagram of (a) "acac", (b) "nacnac", and (c) "cyclopentadienyl" ligands.

diketimines with $\mathrm{N}$-aryl substituents can be synthesized in one step from commercially available anilines and diones through simple condensation reactions (McGeachin 1968; Stender et al. 2001). $\beta$-Diketiminates with aliphatic nitrogen substituents can also be prepared by related condensation routes, but often require harsh reagents such as oxonium salts for complete diimine formation (Kuhn et al. 1999). Other variants of the $\beta$-diketiminate scaffold have been recently discussed in a comprehensive review (Bourget-Merle et al. 2002). Herein, we demonstrate a synthetic pathway for unsymmetrical $\beta$-diketimines and provide detailed characterization by spectroscopic $\left({ }^{1} \mathrm{H}\right.$ NMR, ${ }^{13} \mathrm{C}$ NMR and mass) methods, melting point determination, thermogravimetric analysis (TGA), differential temperature analysis (DTA), and elemental analysis. In addition, the solid state structures of the compounds $4 \mathrm{a}-\mathbf{d}$ have been analyzed by single crystal X-ray diffraction.

\section{Results and discussion}

\section{Synthesis}

The synthetic pathway for unsymmetrical $\beta$-diketiminates described in this work is outlined in Scheme 2. As depicted in Scheme 2, the unsymmetrical $\beta$-diketimines 4a-d were synthesized in two steps: (1) condensation of acetylacetone with one equiv. of primary aromatic amine 2,6-diisopropylaniline in methanol, with formic acid as catalyst, afforded the (Z)-4-(2,6-diisopropylphenylamino)pent-3-en-2-one intermediate 3; (2) another equiv. of the other aromatic amine (aniline, 4-methylaniline, 4- methoxyaniline, and 4-chlororlaniline) was pre-treated with para-toluenesulfonic acid in a $1: 1$ ratio for $3 \mathrm{~h}$ to afford para-toluenesulfonate, which was then reacted with the (Z)-4-(2,6-diisopropylphenylamino)pent-3-en-2one intermediate 3 to give unsymmetrical $\beta$-diketimines $4 a-d$ in good yields. In the second step, the one-pot reaction of (Z)-4-(2,6-diisopropylphenylamino)pent-3-en-2one 3, aromatic amine and para-toluenesulfonic acid failed to give any target product; the reaction of (Z)-4(2,6-diisopropylphenylamino)pent-3-en-2-one with the para-toluenesulfonic acid took place instead, preventing further reaction with the aromatic amine.

\section{${ }^{1} \mathrm{H}-\mathrm{NMR}$ and ${ }^{13} \mathrm{C}$-NMR spectra}

The ${ }^{1} \mathrm{H}$ NMR spectra of all the unsymmetrical $\beta$-diketimines show a characteristic downfield shift in the range $\delta=12.87-13.14 \mathrm{ppm}$ for the $\mathrm{NH}$ proton and high field shift in the range $\delta=4.79-4.84 \mathrm{ppm}$ for the methyne proton attributable to the formation of unsymmetrical $\beta$-diketimines from (Z)-4-(2,6-diisopropylphenylamino) pent-3-en-2-one and amines. Two sharp singlets observed at the range 1.69-1.83 and 1.56-1.65 ppm are assigned to the protons of the two methyl groups $\left(\mathrm{CH}_{3} \mathrm{C}=\mathrm{NAr}\right.$ and $\mathrm{CH}_{3} \mathrm{CNHAr}$ ) of the unsymmetrical $\beta$-diketiminates. The resonance due to the four $\mathrm{CH}_{3}$ protons $\left(\mathrm{CH}\left(\mathrm{CH}_{3}\right)_{2}\right)$ were observed as a two doublets at the range 1.15-1.19 and 1.09-1.14 ppm while that of $\mathrm{CH}$ appeared as a septet at the range 3.12-3.18 ppm.

The ${ }^{13} \mathrm{C}$ NMR is in good agreement with the proposed unsymmetrical $\beta$-diketiminate structures as well. The ${ }^{13} \mathrm{C}$-NMR spectra of unsymmetrical $\beta$-diketiminates showed a peak at the range 161.8-164.1 ppm which is assigned to carbon of the $\mathrm{C}=\mathrm{N}$ group. The methyne carbon appears at the range 95.9-96.6 ppm. Four peaks at the range 24.3-28.7, 20.3-20.6, 21-22.8 and 20.7-21.2 $\mathrm{ppm}$ are due to carbons of the six methyl groups $\left(\mathrm{CH}_{3} \mathrm{C}=\mathrm{NAr}, \mathrm{CH}_{3} \mathrm{CNHAr}\right.$ and $\left.\mathrm{CH}\left(\mathrm{CH}_{3}\right)_{2}\right)$ respectively. In addition, their identities have also been confirmed by a molecular ion peak $\left[\mathrm{M}^{+}\right]$from GC-MS mass spectra.

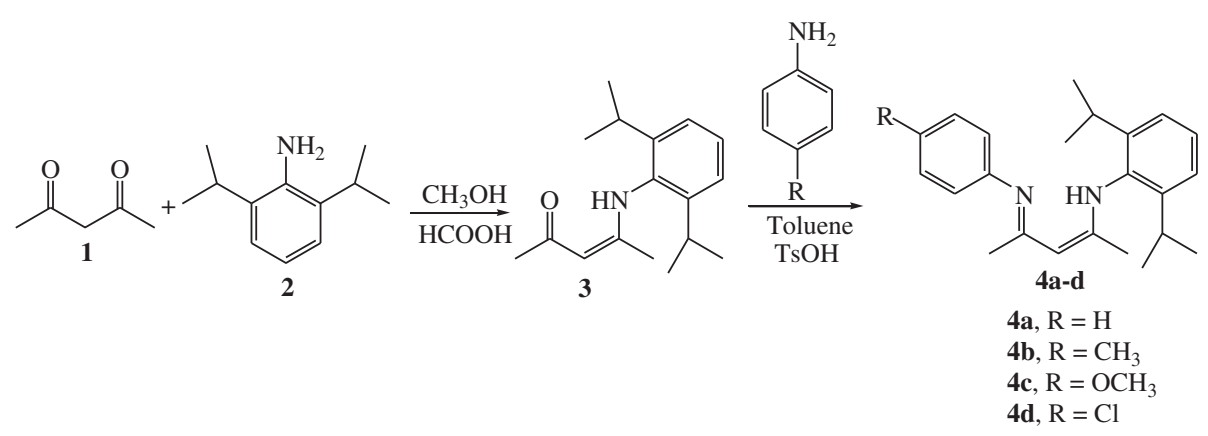

Scheme 2 General reaction scheme for the synthesis of unsymmetrical $\beta$-diketiminates $4 a-d$. 


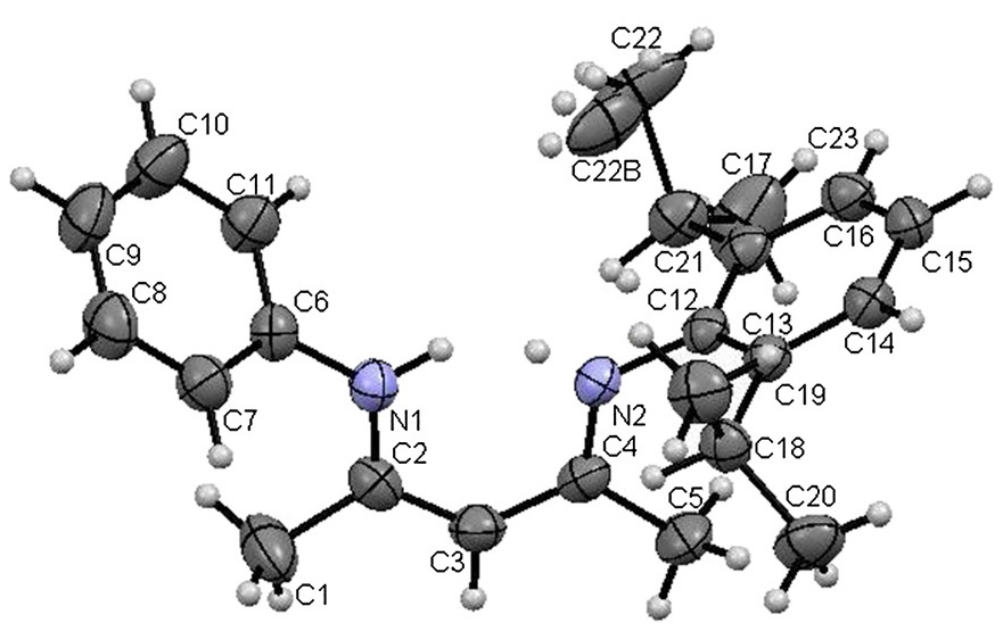

Figure 1 X-ray diffraction structure of $4 a$; molecule; thermal ellipsoids are drawn on the $50 \%$ probability level.

\section{FT-IR spectra}

The FT-IR spectra for the compounds $\mathbf{4 a - d}$ are recorded in the solid state using the $\mathrm{KBr}$ disc technique at the region from 400 to $4000 \mathrm{~cm}^{-1}$. The $(\mathrm{C}=\mathrm{N})$ bands are observed at $1645-1557(\mathrm{v}) \mathrm{cm}^{-1}$; the position of these bands varies with the molecular structure, though no regularity can be pointed out. The bands at the range $3055-3072(v) \mathrm{cm}^{-1}$ is typical of the $\mathrm{NH}$ group. Weak to medium absorptions around $3100-3000 \mathrm{~cm}^{-1}$ observed corresponding to the $=\mathrm{C}-\mathrm{H}$ stretch of aromatic ring.

\section{X-ray crystal structure}

Single crystals of unsymmetrical $\beta$-diketiminates $4 \mathbf{a}-\mathbf{d}$ were grown by the slow evaporation method using methanol as the solvent at room temperature. The solid state structures of $\mathbf{4 a - d}$ with an atom-numbering scheme are shown in Figures 1, 2, 3 and 4, respectively.
The molecular packing diagrams of $\mathbf{4 a - d}$ are displaced in Figures 5, 6, 7 and 8, respectively. A crystallographic data and refinement detail of the compounds $\mathbf{4 a - d}$ is shown in Table 1, whereas selected bond lengths and bond angles are compiled in Table 2. The analysis of the crystal structures of compounds 4 a-d shows that they are coplanar. Compounds $\mathbf{4 a - d}$ have two aromatic rings and a central linkage. Compounds $\mathbf{4 a - d}$ crystallized in the triclinic space group $P \overline{1}$, with two molecules in the unit cell. In these compounds, there is an absence of any lattice held water molecules or organic solvent molecules in the unit cell of the determined structure. The $\mathrm{N}=\mathrm{C}-\mathrm{C}=\mathrm{C}-\mathrm{NH}$ linkage of the compounds $\mathbf{4 a - d}$ is planar; the bond lengths [Table 2] indicate electron delocalization. The $\mathrm{C}-\mathrm{C}$ bond distances in aromatic rings are in the normal range of $1.37-1.48 \mathrm{~A}^{\circ}$, which is characteristic of delocalized aromatic rings. The $\mathrm{C}-\mathrm{C}-\mathrm{C}$ bond

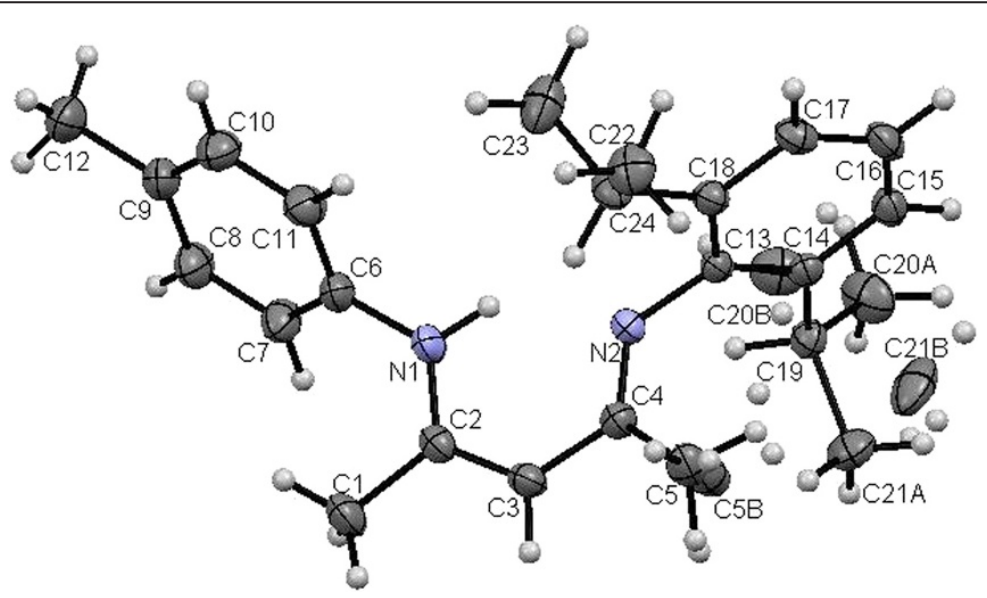

Figure 2 X-ray diffraction structure of $4 \mathrm{~b}$; molecule; thermal ellipsoids are drawn on the $50 \%$ probability level. 


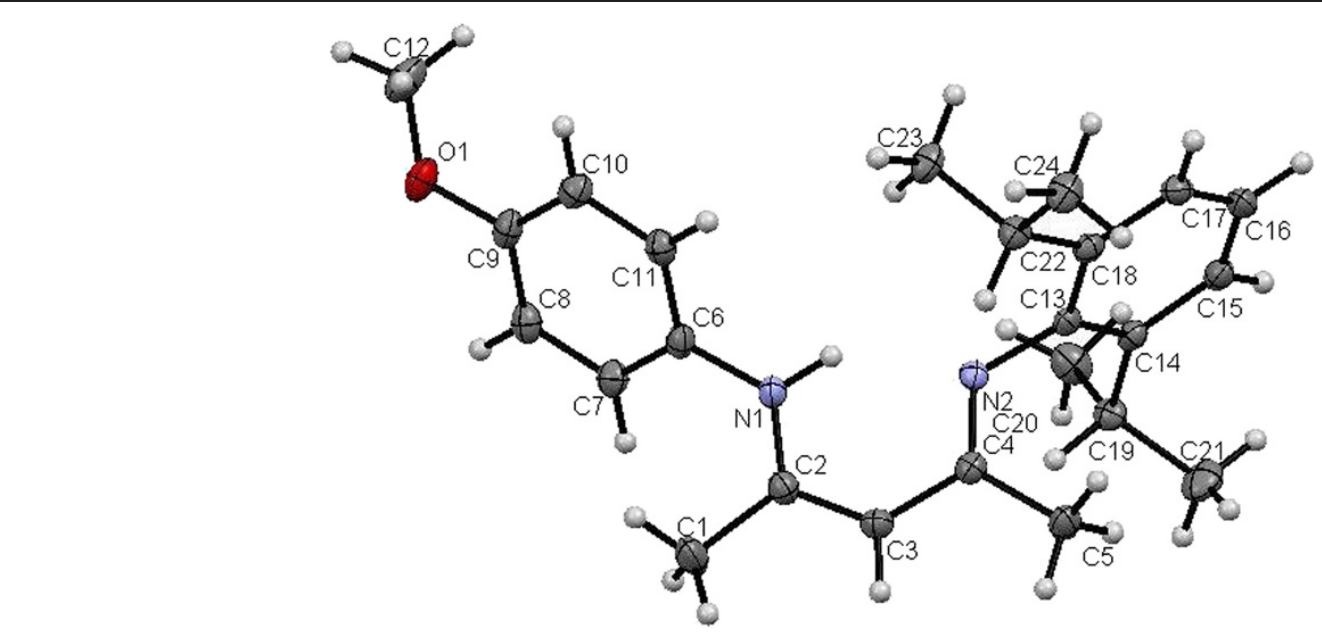

Figure 3 X-ray diffraction structure of $4 c$; molecule; thermal ellipsoids are drawn on the $50 \%$ probability level.

angles in aromatic rings are around $120^{\circ}$ with the variation being less than $2^{\circ}$, which is characteristic of $\mathrm{sp}^{2}$ hybridized carbons. The molecular packing diagrams of all the four unsymmetrical $\beta$-diketiminates $4 \mathbf{a}$-d showed two layers of molecules, which are independently arranged in the unit cell. Molecules forming each layer are not connected through intermolecular hydrogen bonding. In each layer, the molecules are alternatively parallel. The molecular packing diagram also shows the presence of one intra-molecular hydrogen bond. One of the hydrogens, $\mathrm{H} 1$ of the $\mathrm{NH}$ group, is involved in intramolecular hydrogen bonding with the $\mathrm{N} 2$ of the $\mathrm{C}=\mathrm{N}$ entity. This hydrogen bonding stabilizes the crystal packing.

\section{Mass spectra and thermal studies}

The mass spectra were analyzed by GC-MS. The peaks observed at $\mathrm{m} / \mathrm{z} 334.49,348.47,364.36$, and 368.92 suggested the molecular formulas $\mathrm{C}_{23} \mathrm{H}_{30} \mathrm{~N}_{2}, \mathrm{C}_{24} \mathrm{H}_{32} \mathrm{~N}_{2}$, $\mathrm{C}_{24} \mathrm{H}_{32} \mathrm{~N}_{2} \mathrm{O}$, and $\mathrm{C}_{23} \mathrm{H}_{29} \mathrm{ClN}_{2}$ of the compounds 4a-d respectively.

The thermal behavior of the compounds 4a-d have been investigated using thermogravimetric techniques in the temperature range from $25^{\circ} \mathrm{C}$ to $1000^{\circ} \mathrm{C}$ at a heating rate of $10^{\circ} \mathrm{C} \mathrm{min}^{-1}$ under inert nitrogen gas flow. On the temperature difference curves seen in Figure 9, sharp endothermic peaks were observed at temperatures of $92.55,93.51,109.60$ and $115.43^{\circ} \mathrm{C}$, this indicates that the compounds 4a-d melt at 92.55, 93.51, 109.60 and $115.43^{\circ} \mathrm{C}$, respectively. Further confirmation of their melting point by glass capillary analysis provided values of 93.0, 94.0, 110.0 and $116.0^{\circ} \mathrm{C}$ for the compounds 4a-d. The symmetric analogues 2-((phenyl)amino)-4((phenyl)imino)-2-pentene, 2-((4-methylphenyl)amino)-4((4-methylphenyl)imino)-2-pentene, 2-((4-methoxyphenyl) amino)-4-((4-methoxyphenyl)imino)-2-pentene and 2-((4-

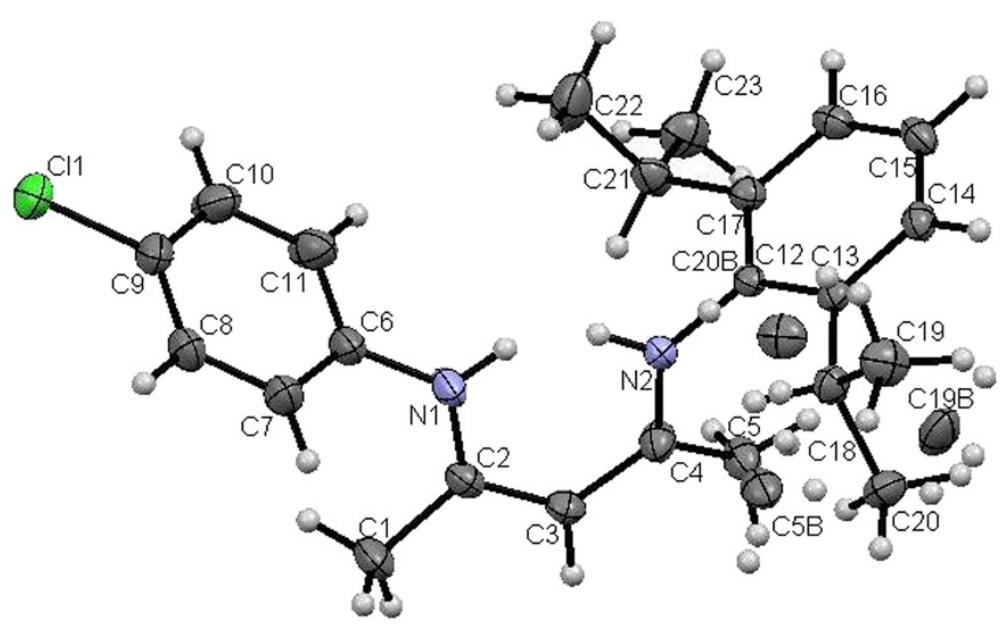

Figure 4 X-ray diffraction structure of $4 \mathrm{~d}$; molecule; thermal ellipsoids are drawn on the $50 \%$ probability level. 


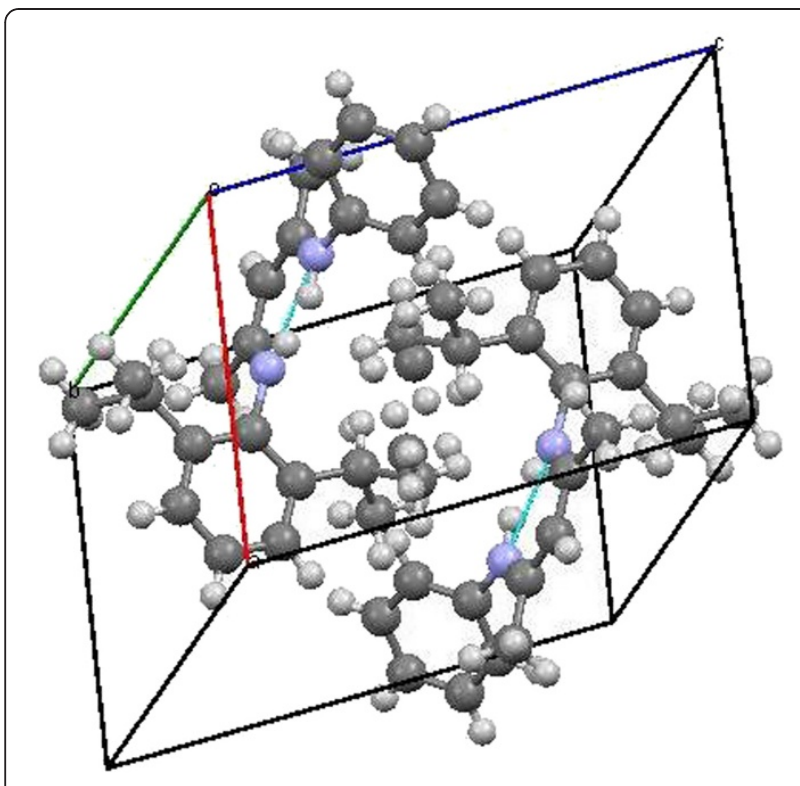

Figure 5 Perspective view of the molecular packing of $4 a$ showing the intramolecular hydrogen bondings.

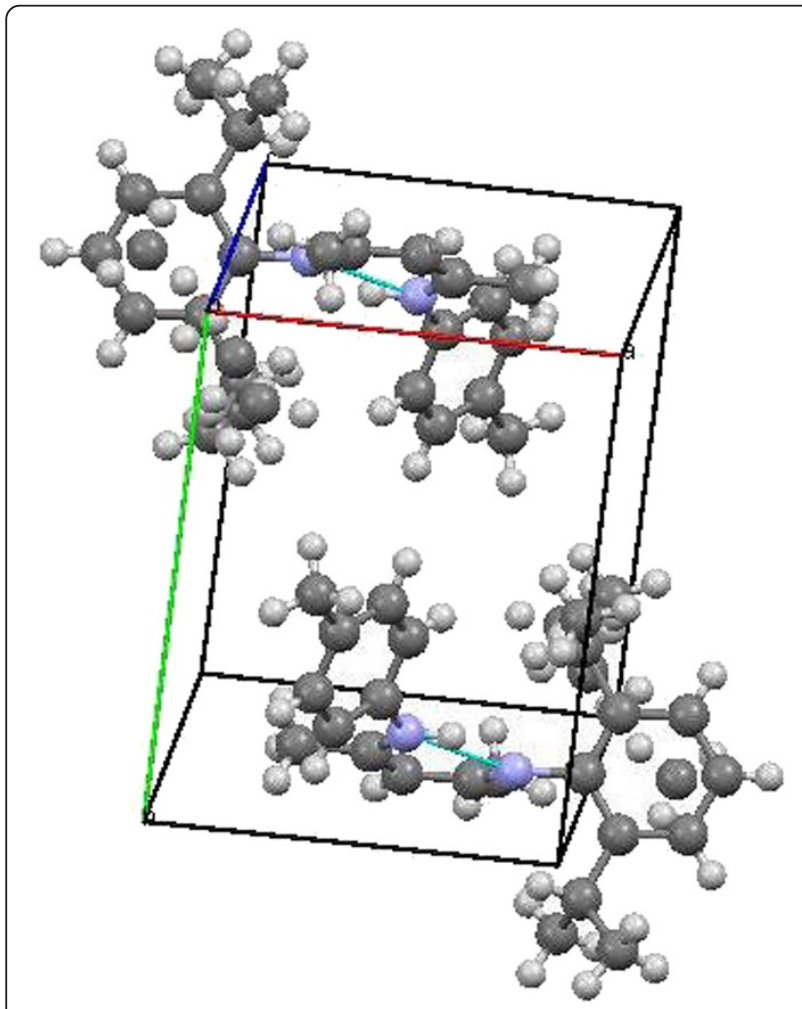

Figure 6 Perspective view of the molecular packing of $4 \mathrm{~b}$ showing the intramolecular hydrogen bondings. chlorophenyl)amino)-4-((4-chlorophenyl)imino)-2-pentene melt at 51,73, 94 and $86^{\circ} \mathrm{C}$, respectively (Gong and $\mathrm{Ma}$ 2008; Tang et al. 2006). At temperatures of 221.50, 238.82, 329.22 and $243.25^{\circ} \mathrm{C}$, additional sharp endothermic peaks occurred corresponding to boiling points of the compounds 4a-d. Onsets of mass loss in the compounds 4a-d occurred at $77.17,85.29,91.38$ and $93.41^{\circ} \mathrm{C}$ and terminated at $243.66,258.89,329.95$ and $260.92^{\circ} \mathrm{C}$ as observed by the weight loss curve of the TGA data for each compound.

\section{Conclusions}

All the four unsymmetrical $\beta$-diketiminates (4a-d) were synthesized. The structures were identified by spectroscopic methods ( ${ }^{1} \mathrm{H}$ NMR, ${ }^{13} \mathrm{C}$ NMR, IR and mass), thermogravimetric analysis (TGA), differential temperature analysis (DTA), elemental analysis, and X-ray diffraction analyses. TGA/DTA analyses of all the four unsymmetrical $\beta$-diketiminates 4a-d were studied, showing two distinct endothermic peaks at temperatures of 92.55 , 93.51, $109.60,115.43^{\circ} \mathrm{C}$ and $221.50,238.82,329.22$, $243.25^{\circ} \mathrm{C}$, corresponding to melting and boiling points, respectively.

\section{Experimental section}

\section{General information on reagents and techniques}

Reactions were carried out under aerobic conditions. All reagents and solvents are of analytical grade; they were purchased and used without further purification. Acetylacetone, aniline, 4-methylaniline, 4-methoxyaniline, 4chlororlaniline, formic acid, para-toluenesulfoinc acid monohydrate, $\mathrm{MgSO}_{4}$, and sodium carbonate were procured commercially from Sigma-Aldrich chemical company, and were used without further purification. Nuclear magnetic resonance (NMR) spectra were obtained using a $1.0 \%$ to $2.5 \%$ solution in deuterated benzene $\left(\mathrm{C}_{6} \mathrm{D}_{6}\right) .{ }^{1} \mathrm{H}$ and ${ }^{13} \mathrm{C}$ NMR spectra were recorded on a Varian Mercury $500 \mathrm{MHz}$ spectrometer. Proton and carbon chemical shifts are reported in parts-permillion $(\delta)$ with respect to tetramethylsilane (TMS) as internal reference $(\delta=0.0 \mathrm{ppm})$. IR spectra were recorded on a Perkin Elmer Paragon 1000 FT-IR spectrometer employing a $\mathrm{KBr}$ disc. Mass spectra were obtained on a GC-MS instrument operating in TOF-MI ${ }^{+}$ mode. $\mathrm{CHN}$ analysis was done by Atlantic Microlab using a CE-1108 Elemental Analyzer, and values were within $\pm 0.4 \%$ of the theoretical values. Thermogravimetric analyses (TGA) were made with a Pyris TGA instrument. A heating rate of $10^{\circ} \mathrm{C} / \mathrm{min}$ was used and samples $(5-10 \mathrm{mg}$ ) were contained in a platinum pan. The sample compartment was purged with dry nitrogen at $50 \mathrm{~mL} / \mathrm{min}$ during analysis. TA Thermal Advantage software was used for data analysis. Melting points were determined using a Pyris differential scanning calorimeter (DSC). The crystallographic 


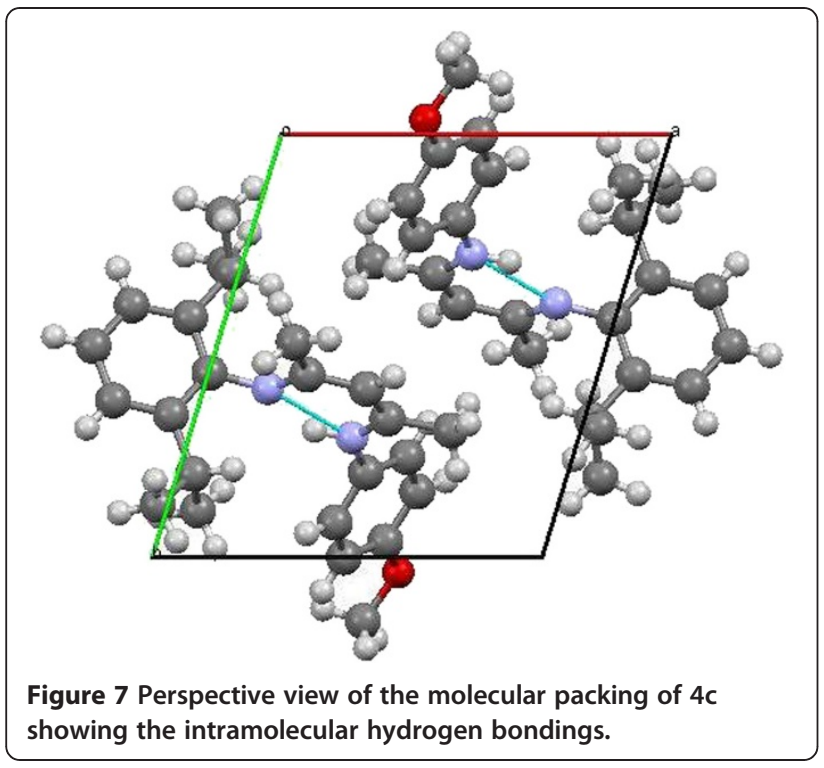

data for compounds 4a-d were collected on a Bruker SMART APEX II diffractometer. The APEX2 (Version 2010.9-0, 2010) program package was used to determine the unit-cell parameters and for data collection. The raw frame data was processed using SAINT (Version and 7.68a, 2009) and SADABS Sheldrick (2008a) to yield the reflection data file. Subsequent calculations were carried out using the SHELXTL (Sheldrick 2008b) program. The structures were solved by direct methods and refined on $\mathrm{F}^{2}$ by fullmatrix least-squares techniques. The analytical scattering factors $^{21}$ for neutral atoms were used throughout the analysis. Hydrogen atoms were included using a riding model.

Crystallographic data for the structures reported in this article have been deposited with the Cambridge Crystallographic Data Center with the deposition

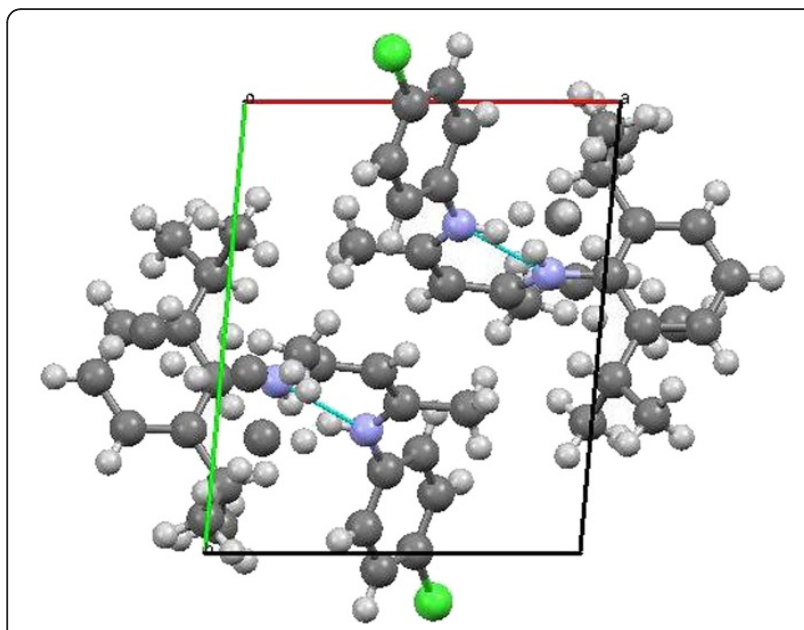

Figure 8 Perspective view of the molecular packing of $4 d$ showing the intramolecular hydrogen bondings. numbers 903786, 903787, 903788, and 903789. A copy of the data can be obtained free of charge from the Director, CCDC, 12 Union Road, Cambridge CB2 1EZ, UK [fax: +44 1223 336-033; e-mail: deposit@ccdc.cam.ac.uk or www.ccdc.cam.ac.uk].

4-(2,6-diisopropylphenyl)amino-3-penten-2-one (3). 2,6-Diisopropylaniline (1.77 g, $10.0 \mathrm{mmol})$ was mixed with acetylacetone $(1.0 \mathrm{~g}, 10.0 \mathrm{mmol})$ in $40 \mathrm{~mL}$ of methanol containing a catalytic amount (2 drops) of formic acid. The solution was heated at $85^{\circ} \mathrm{C}$ for $6-8 \mathrm{~h}$. Removal of volatiles afforded a pale brown oil. This was then stirred with $20 \mathrm{~mL} 40-60^{\circ} \mathrm{C}$ petroleum ether at $-30^{\circ} \mathrm{C}$ to precipitate a white solid which was filtered off, washed with $2 \times 10 \mathrm{~mL}$ cold hexane $\left(-78^{\circ} \mathrm{C}\right)$, and dried in vacuo. Yield: $2.30 \mathrm{~g}(89 \%) .{ }^{1} \mathrm{H}$ NMR $(500 \mathrm{MHz}$, $\left.\mathrm{C}_{6} \mathrm{D}_{6}\right) \delta(\mathrm{ppm}): 12.66(1 \mathrm{H}, \mathrm{s}, \mathrm{NH}), 7.11-7.06(\mathrm{~m}, 1 \mathrm{H}$, $\mathrm{ArH})$, 6.97-6.94 (m, 2H, $\mathrm{ArH}), 5.08\left(\mathrm{~s}, 1 \mathrm{H}, \mathrm{CH}=\mathrm{C}\left(\mathrm{CH}_{3}\right)\right.$ $\mathrm{N}), 3.04$ (sept, J = $\left.6.8 \mathrm{~Hz}, 2 \mathrm{H}, \mathrm{CH}\left(\mathrm{CH}_{3}\right)_{2}\right), 2.01(\mathrm{~s}, 3 \mathrm{H}$, $\mathrm{CH}_{3} \mathrm{COC}$ ), 1.34 (s, 3H, $\left.\mathrm{CH}_{3} \mathrm{CNHAr}\right), 1.02(\mathrm{~d}, \mathrm{~J}=6.9 \mathrm{~Hz}$, $\left.6 \mathrm{H}, \mathrm{CH}\left(\mathrm{CH}_{3}\right)_{2}\right), 0.96\left(\mathrm{~d}, \mathrm{~J}=6.9 \mathrm{~Hz}, 6 \mathrm{H}, \mathrm{CH}\left(\mathrm{CH}_{3}\right)_{2}\right) .{ }^{13} \mathrm{C}$ NMR (100 MHz, $\left.\mathrm{C}_{6} \mathrm{D}_{6}\right) \delta(\mathrm{ppm}): 195.69(\mathrm{C}=\mathrm{O}), 162.40$ (HC(CNHAr), 146.60 (Ar-C), 134.23 (Ar-C), 128.50 (ArC), 123.78 (Ar-C), $95.93(\mathrm{CH}), 29.04\left(\mathrm{CH}_{3} \mathrm{C}=\mathrm{O}\right), 28.80$ $\left(\mathrm{CH}\left(\mathrm{CH}_{3}\right)_{2}\right), 24.53\left(\mathrm{CH}\left(\mathrm{CH}_{3}\right)_{2}, 22.61\left(\mathrm{CH}\left(\mathrm{CH}_{3}\right)_{2}\right), 18.85\right.$ $\left(\mathrm{CH}_{3} \mathrm{CNHAr}\right.$ ). Mass data (TOF MS $\left.\mathrm{EI}^{+}\right)$: Calcd for $\mathrm{C}_{17} \mathrm{H}_{25} \mathrm{NO}\left[\mathrm{M}^{+}\right]$259.39, found: 259.21. Anal. Calcd for $\mathrm{C}_{17} \mathrm{H}_{25} \mathrm{NO}$ : C, 78.72; H, 9.71; N, 5.40; Found: C, 78.61; $\mathrm{H}, 9.59 ; \mathrm{N}, 5.36$. IR (KBr, $\left.\mathrm{cm}^{-1}\right)$ v: $3418(\mathrm{~m}), 2972(\mathrm{w})$, 16015 (s), $1573(\mathrm{~m}), 1515(\mathrm{~m}), 1467$ (w), $1411(\mathrm{~m}), 1397$ (m), 1344 (m), $1299(\mathrm{w}), 1203(\mathrm{w}), 1137(\mathrm{~m}), 1076(\mathrm{w})$, $983(\mathrm{~m}), 842(\mathrm{w}), 722(\mathrm{w}), 601(\mathrm{~m}), 513(\mathrm{~m}), 484(\mathrm{w})$.

2-(2,6-diisopropylphenyl)amino-4-(phenyl)imino- 2 pentene (4a). Aniline (4.55 g, $50.00 \mathrm{mmol})$, and paratoluenesulfonic acid monohydrate $(9.510 \mathrm{~g}, 50.00 \mathrm{mmol})$ in $100 \mathrm{~mL}$ of toluene were stirred for approximately $3 \mathrm{~h}$ at room temperature. To the obtained yellow suspension, 4-(2,6-diisopropylphenyl)amino-3-penten-2-one (12.97 g, $50.00 \mathrm{mmol}$ ) was added. A Dean-Stark apparatus was attached and the mixture was heated at reflux for $24 \mathrm{~h}$ to remove the water. The reaction mixture was cooled to room temperature and all the volatiles were removed under reduced pressure to give a yellow solid. The solid was treated with diethyl ether $(100 \mathrm{~mL})$, water $(100 \mathrm{~mL})$ and sodium carbonate $(10.60 \mathrm{~g}, 100 \mathrm{mmol})$, and the obtained mixture was kept stirring. After complete dissolution, the aqueous phase was separated and extracted with diethyl ether. The combined organic phase was dried over $\mathrm{MgSO}_{4}$ and rotary evaporated to dryness under reduced pressure to afford a brownish yellow solid. Yellow crystals (12.95 g, 77\%) were obtained after recrystallization from methanol. ${ }^{1} \mathrm{H}$ NMR (500 MHz, $\left.\mathrm{C}_{6} \mathrm{D}_{6}\right) \delta$ (ppm): $13.14(\mathrm{~s}, 1 \mathrm{H}, \mathrm{NH}), 7.16-7.14$ (m, 3H, ArH), 7.10-7.09 (m, 2H, ArH), 6.97-6.94 (m, 2H, 
Table 1 Crystal data and the structure refinement of the compounds $4 a-d$

\begin{tabular}{|c|c|c|c|c|}
\hline Identification code & $4 a$ & $4 b$ & $4 c$ & $4 d$ \\
\hline Empirical formula & $\mathrm{C}_{23} \mathrm{H}_{30} \mathrm{~N}_{2}$ & $\mathrm{C}_{24} \mathrm{H}_{32} \mathrm{~N}_{2}$ & $\mathrm{C}_{24} \mathrm{H}_{32} \mathrm{~N}_{2} \mathrm{O}$ & $\mathrm{C}_{23} \mathrm{H}_{29} \mathrm{Cl} \mathrm{N}_{2}$ \\
\hline Formula weight & 334.49 & 348.52 & 364.52 & 368.93 \\
\hline Temperature (K) & $198(2)$ & $143(2)$ & $88(2)$ & $143(2)$ \\
\hline Wavelength $(\AA ̊)$ & 0.71073 & 0.71073 & 0.71073 & 0.71073 \\
\hline Crystal system & Triclinic & Triclinic & Triclinic & Triclinic \\
\hline Space group & $P \overline{1}$ & $P \overline{1}$ & $P \overline{1}$ & $P \overline{1}$ \\
\hline \multicolumn{5}{|l|}{ Unit cell dimensions } \\
\hline $\mathrm{a}(\AA)$ & $9.6209(4)$ & $8.9868(7)$ & $9.4632(5)$ & $8.8970(6)$ \\
\hline$b(\AA)$ & $11.0221(5)$ & 10.3608(8) & $10.3455(5)$ & $10.3481(6)$ \\
\hline$c(\AA)$ & $11.0824(5)$ & $12.0081(9)$ & $12.0086(6)$ & $11.9800(8)$ \\
\hline$a\left(^{\circ}\right)$ & $112.2432(5)$ & $98.8602(9)$ & $92.8431(6)$ & $98.9102(7)$ \\
\hline$\beta\left(^{\circ}\right)$ & $97.8486(5)$ & $106.9857(8)^{\circ}$ & $106.1653(5)$ & $107.4484(6)$ \\
\hline$Y\left(^{\circ}\right)$ & $102.1196(5)$ & $93.2382(9)^{\circ}$ & $105.4519(6)$ & $92.1628(7)$ \\
\hline Volume $\left(\AA^{3}\right)$ & 1032.76(8) & $1050.44(14)$ & 1078.59(9) & 1035.36(12) \\
\hline Z & 2 & 2 & 2 & 2 \\
\hline Density (calculated) $\left(\mathrm{Mg} / \mathrm{m}^{3}\right)$ & 1.076 & 1.102 & 1.122 & 1.183 \\
\hline Absorption coefficient $\left(\mathrm{mm}^{-1}\right)$ & 0.062 & 0.064 & 0.068 & 0.193 \\
\hline $\mathrm{F}_{000}$ & 364 & 380 & 396 & 396 \\
\hline Crystal size $\left(\mathrm{mm}^{3}\right)$ & $0.42 \times 0.33 \times 0.26$ & $0.33 \times 0.31 \times 0.25$ & $0.36 \times 0.36 \times 0.23$ & $0.38 \times 0.37 \times 0.26$ \\
\hline Theta range for data collection $\left({ }^{\circ}\right)$ & 2.04 to 26.37 & 1.80 to 28.40 & 1.78 to 28.82 & 1.81 to 28.54 \\
\hline Index ranges & $\begin{array}{l}-12 \leq h \leq 12,-13 \leq \\
k \leq 13,-13 \leq l \leq 13\end{array}$ & $\begin{array}{l}12 \leq h \leq 11,-13 \leq k \leq \\
13,-15 \leq 1 \leq 15\end{array}$ & $\begin{array}{l}-12 \leq h \leq 12,-13 \leq k \leq \\
13,-15 \leq 1 \leq 16\end{array}$ & $\begin{array}{l}-11 \leq h \leq 11,-13 \\
\leq k \leq 13,-15 \leq 1 \leq 15\end{array}$ \\
\hline Reflections collected & 11311 & 12098 & 13056 & 12115 \\
\hline Independent reflections & $4202[\mathrm{R}(\mathrm{int})=0.0142]$ & $4779[\mathrm{R}(\mathrm{int})=0.0145]$ & $5172[R($ int $)=0.0138]$ & $4753[\mathrm{R}(\mathrm{int})=0.0172]$ \\
\hline Refinement method & $\begin{array}{l}\text { Full-matrix least-squares } \\
\text { on } \mathrm{F}^{2}\end{array}$ & $\begin{array}{l}\text { Full-matrix least-squares } \\
\text { on } \mathrm{F}^{2}\end{array}$ & $\begin{array}{l}\text { Full-matrix least-squares } \\
\text { on } \mathrm{F}^{2}\end{array}$ & $\begin{array}{l}\text { Full-matrix least-squares } \\
\text { on } \mathrm{F}^{2}\end{array}$ \\
\hline Completeness to theta $=25.50^{\circ}$ & $99.7 \%$ & $99.6 \%$ & $99.7 \%$ & $99.6 \%$ \\
\hline Max. and min. Transmission & 0.9842 and 0.9742 & 0.9842 and 0.9794 & 0.9846 and 0.9760 & 0.9522 and 0.9295 \\
\hline Data / restraints / parameters & 4202 / 0 / 251 & 4779 / 0 / 277 & $5172 / 0 / 255$ & $4753 / 0 / 348$ \\
\hline Goodness-of-fit on $F^{2}$ & 1.049 & 1.037 & 1.072 & 1.049 \\
\hline Final $R$ indices $[\mid>2$ sigma(l)] & $\mathrm{R} 1=0.0436, \mathrm{wR} 2=0.1186$ & $\mathrm{R} 1=0.0438, w R 2=0.1149$ & $R 1=0.0407, w R 2=0.1089$ & $\mathrm{R} 1=0.0366, w R 2=0.0996$ \\
\hline R indices (all data) & $\mathrm{R} 1=0.0505, w R 2=0.1248$ & $\mathrm{R} 1=0.0535, \mathrm{wR} 2=0.1225$ & $R 1=0.0452, w R 2=0.1126$ & $R 1=0.0406, w R 2=0.1031$ \\
\hline Largest diff. peak and hole $\left(\mathrm{e} . \AA^{-3}\right)$ & 0.264 and -0.197 & 0.264 and -0.201 & 0.328 and -0.325 & 0.328 and -0.225 \\
\hline
\end{tabular}

$\mathrm{ArH})$, 6.88-6.85 (m, 1H, $\mathrm{ArH}), 4.84\left(\mathrm{~s}, 1 \mathrm{H}, \mathrm{CH}=\mathrm{C}\left(\mathrm{CH}_{3}\right)\right.$ $\mathrm{N}), 3.18$ (sept, J = 6.8 Hz, $\left.2 \mathrm{H}, \mathrm{CH}\left(\mathrm{CH}_{3}\right)_{2}\right), 1.82(\mathrm{~s}, 3 \mathrm{H}$, $\mathrm{CH}_{3} \mathrm{C}=\mathrm{NAr}$ ), 1.63 (s, 3H, $\mathrm{CH}_{3} \mathrm{CNHAr}$ ), 1.19 (d, J = 7.0 $\left.\mathrm{Hz}, 6 \mathrm{H}, \mathrm{CH}\left(\mathrm{CH}_{3}\right)_{2}\right), 1.14\left(\mathrm{~d}, \mathrm{~J}=7.0 \mathrm{~Hz}, 6 \mathrm{H}, \mathrm{CH}\left(\mathrm{CH}_{3}\right)_{2}\right)$. ${ }^{13} \mathrm{C}$ NMR $\left(100 \mathrm{MHz}, \mathrm{C}_{6} \mathrm{D}_{6}\right) \delta(\mathrm{ppm}): 163.1\left(\mathrm{NCCH}_{3}\right)$, $157.3\left(\mathrm{NCCH}_{3}\right), 144.9$ (Ar-C), 142.8 (Ar-C), 141.1 (ArC), 129.2 (Ar-C), 125.2 (Ar-C), 123.4 (Ar-C), 123.3 (ArC), 122.7 (Ar-C), $96.6(\mathrm{CH}), 28.7\left(\mathrm{CH}_{3} \mathrm{C}=\mathrm{NAr}\right), 24.3$ $\left(\mathrm{CH}\left(\mathrm{CH}_{3}\right)_{2}\right), 22.7\left(\mathrm{CH}\left(\mathrm{CH}_{3}\right)_{2}\right), 21.0\left(\mathrm{CH}\left(\mathrm{CH}_{3}\right)_{2}\right), 20.6$ $\left(\mathrm{CH}_{3} \mathrm{CNHAr}\right.$ ). Melting point: $93.0^{\circ} \mathrm{C}$. Mass data (TOF MS EI ${ }^{+}$): Calcd for $\mathrm{C}_{23} \mathrm{H}_{30} \mathrm{~N}_{2}\left[\mathrm{M}^{+}\right]$334.50, found: 334.49. Anal. Calcd for $\mathrm{C}_{23} \mathrm{H}_{30} \mathrm{~N}_{2}$ : C, 82.59; H, 9.04; N,
8.37; Found: C, 82.55; H, 9.01; N, 8.41. IR $\left(\mathrm{KBr}, \mathrm{cm}^{-1}\right)$ v: 3055 (w), 2960 (w), 2920 (w), $2875(w), 1925(w), 1873$ (w), $1800(\mathrm{w}), 1740(\mathrm{w}), 1630(\mathrm{~s}), 1547$ (s), $1489(\mathrm{w}), 1360$ (m), $1275(\mathrm{~m}), 1260(\mathrm{~m}), 1155(\mathrm{~s}), 1100(\mathrm{w}), 1030(\mathrm{w})$, 800 (s), 798 (s), 750 (s), 699 (m), 595 (w), 501 (w), 425 (m).

2-(2,6-diisopropylphenyl)amino-4-(4-methylphenyl) imino-2-pentene (4b). $\beta$-Diketiminate $4 \mathrm{~b}$ was synthesized by the same procedure as $4 \mathbf{a}$. Yield (14.02 g, 80\%). ${ }^{1} \mathrm{H}$ NMR (500 MHz, $\left.\mathrm{C}_{6} \mathrm{D}_{6}\right) \delta$ (ppm): 13.11 (s, 1H, NH), 7.13-7.11 (m, 3H, ArH), 6.89-6.85 (m, 4H, ArH), 4.83 (s, 
Table 2 Selected bond lengths and bonds angles of the compounds 4a-d

\begin{tabular}{|c|c|c|c|c|}
\hline Bond length (Å) & $4 a$ & $4 b$ & $4 c$ & $4 d$ \\
\hline$N(1)-C(2)$ & $1.3269(16)$ & $1.3476(15)$ & $1.3530(13)$ & $1.3293(15)$ \\
\hline$N(1)-C(6)$ & $1.4151(15)$ & $1.4220(15)$ & $1.4222(12)$ & $1.4148(15)$ \\
\hline$N(2)-C(4)$ & $1.3231(15)$ & $1.2965(14)$ & $1.3036(13)$ & $1.3154(14)$ \\
\hline$N(2)-C(12)$ & $1.4270(14)$ & & & $1.4268(13)$ \\
\hline$N(2)-C(13)$ & & $1.4240(13)$ & $1.4234(12)$ & \\
\hline$C(1)-C(2)$ & $1.5065(18)$ & $1.5015(16)$ & $1.5039(14)$ & $1.5059(15)$ \\
\hline$C(2)-C(3)$ & $1.4001(17)$ & $1.3680(16)$ & $1.3777(14)$ & $1.3897(16)$ \\
\hline$C(3)-C(4)$ & $1.3987(17)$ & $1.4352(16)$ & $1.4382(13)$ & $1.4091(15)$ \\
\hline$C(4)-C(5)$ & $1.5065(16)$ & $1.551(6)$ & $1.5144(13)$ & $1.561(3)$ \\
\hline$C(9)-C(12)$ & & $1.5093(18)$ & & \\
\hline$O(1)-C(9)$ & & & $1.3706(12)$ & \\
\hline$O(1)-C(12)$ & & & $1.4283(15)$ & \\
\hline $\mathrm{Cl}(1)-\mathrm{C}(9)$ & & & & $1.7408(12)$ \\
\hline Bond angles $\left({ }^{\circ}\right)$ & $4 a$ & $4 b$ & $4 c$ & $4 d$ \\
\hline$C(2)-N(1)-C(6)$ & $124.56(11)$ & $126.93(10)$ & 127.61(9) & $124.80(10)$ \\
\hline$C(4)-N(2)-C(12)$ & $123.06(10)$ & & & $122.54(9)$ \\
\hline$N(1)-C(2)-C(3)$ & 120.69(11) & $120.78(10)$ & 120.80(9) & $120.59(10)$ \\
\hline$N(1)-C(2)-C(1)$ & $121.36(12)$ & $119.51(11)$ & 119.58(9) & $121.22(11)$ \\
\hline$C(3)-C(2)-C(1)$ & $117.90(12)$ & $119.69(11)$ & 119.62(9) & $118.17(10)$ \\
\hline$C(4)-C(3)-C(2)$ & $126.12(11)$ & $126.13(10)$ & 125.84(9) & $125.85(10)$ \\
\hline$N(2)-C(4)-C(3)$ & $121.25(11)$ & 121.18(10) & 120.77(9) & 121.65(10) \\
\hline$N(2)-C(4)-C(5)$ & $120.14(11)$ & $122.6(2)$ & 122.63(9) & $119.30(13)$ \\
\hline$C(3)-C(4)-C(5)$ & $118.61(11)$ & $114.4(2)$ & $116.60(8)$ & $116.53(13)$ \\
\hline$C(4)-N(2)-C(13)$ & & $120.72(9)$ & 120.70(8) & \\
\hline$C(9)-O(1)-C(12)$ & & & 116.54(9) & \\
\hline
\end{tabular}

$\left.1 \mathrm{H}, \mathrm{CH}=\mathrm{C}\left(\mathrm{CH}_{3}\right) \mathrm{N}\right), 3.16$ (sept, $\mathrm{J}=6.8 \mathrm{~Hz}, 2 \mathrm{H}, \mathrm{CH}$ $\left.\left(\mathrm{CH}_{3}\right)_{2}\right), 2.05\left(\mathrm{~s}, 3 \mathrm{H}, \mathrm{CH}_{3}\right), 1.83\left(\mathrm{~s}, 3 \mathrm{H}, \mathrm{CH}_{3} \mathrm{C}=\mathrm{NAr}\right)$, $1.63\left(\mathrm{~s}, 3 \mathrm{H}, \mathrm{CH}_{3} \mathrm{CNHAr}\right), 1.17(\mathrm{~d}, 6 \mathrm{H}, \mathrm{J}=7.0 \mathrm{~Hz}$, $\left.\mathrm{CH}\left(\mathrm{CH}_{3}\right)_{2}\right), 1.13\left(\mathrm{~d}, \mathrm{~J}=7.0 \mathrm{~Hz}, 6 \mathrm{H}, \mathrm{CH}\left(\mathrm{CH}_{3}\right)_{2}\right) .{ }^{13} \mathrm{C}$ NMR $\left(100 \mathrm{MHz}, \mathrm{C}_{6} \mathrm{D}_{6}\right) \delta(\mathrm{ppm}): 163.8\left(\mathrm{NCCH}_{3}\right)$, $156.6\left(\mathrm{NCCH}_{3}\right), 143.7$ (Ar-C), 141.6 (Ar-C), 140.5 (Ar-C), 132.8 (Ar-C), 129.8 (Ar-C), 124.8 (Ar-C), 123.4 (Ar-C), 123.1 (Ar-C), $96.4(\mathrm{CH}), 28.7\left(\mathrm{CH}_{3} \mathrm{Ar}\right)$, $24.3\left(\mathrm{CH}_{3} \mathrm{C}=\mathrm{NAr}\right), 22.7\left(\mathrm{CH}\left(\mathrm{CH}_{3}\right)_{2}\right), 21.1\left(\mathrm{CH}\left(\mathrm{CH}_{3}\right)\right.$ 2), $20.7\left(\mathrm{CH}\left(\mathrm{CH}_{3}\right)_{2}\right), \quad 20.5 \quad\left(\mathrm{CH}_{3} \mathrm{CNHAr}\right)$. Melting point: $94.0^{\circ} \mathrm{C}$ Mass data (TOF $\mathrm{MS} \mathrm{EI}^{+}$): Calcd for $\mathrm{C}_{24} \mathrm{H}_{32} \mathrm{~N}_{2}\left[\mathrm{M}^{+}\right]$348.52, found: 348.47. Anal. Calcd for $\mathrm{C}_{24} \mathrm{H}_{32} \mathrm{~N}_{2}$ : C, 82.71; H, 9.25; N, 8.04; Found: C, 82.69; H, 9.17; N, 8.03. IR $\left(\mathrm{KBr}, \mathrm{cm}^{-1}\right)$ v: $3149(\mathrm{w})$, $3072(\mathrm{w}), 3015(\mathrm{w}), 2960(\mathrm{~m}), 1635(\mathrm{w}), 1598(\mathrm{~s}), 1542$ (m), $1468(\mathrm{~m}), 1439(\mathrm{~m}), 1388(\mathrm{w}), 1255(\mathrm{~m}), 1236(\mathrm{~s})$, $1180(\mathrm{w}), 1120(\mathrm{~m}), 1105(\mathrm{~m}), 1037(\mathrm{~m}), 760(\mathrm{~m}), 741$ $(\mathrm{m}), 664(\mathrm{w}), 615(\mathrm{w}), 602(\mathrm{w}), 557(\mathrm{w})$.

2-(2,6-diisopropylphenyl)amino-4-(4-methoxyphenyl) imino-2-pentene (4c). $\beta$-Diketiminate $4 \mathrm{c}$ was synthesized by the same procedure as 4a. Yield (15.25 g, 84\%). ${ }^{1} \mathrm{H}$ NMR $\left(500 \mathrm{MHz}, \mathrm{C}_{6} \mathrm{D}_{6}\right) \delta(\mathrm{ppm}): 13.04(\mathrm{~s}, 1 \mathrm{H}, \mathrm{NH})$, 7.14-7.11 (m, 3H, ArH), 6.87-6.84 (m, 2H, ArH), 6.65$6.63(\mathrm{~m}, 2 \mathrm{H}, \mathrm{ArH}), 4.84\left(\mathrm{~s}, 1 \mathrm{H}, \mathrm{CH}=\mathrm{C}\left(\mathrm{CH}_{3}\right) \mathrm{N}\right), 3.26(\mathrm{~s}$, $\left.3 \mathrm{H}, \mathrm{OCH}_{3}\right), 3.17$ (sept, J = $\left.6.8 \mathrm{~Hz}, 2 \mathrm{H}, \mathrm{CH}\left(\mathrm{CH}_{3}\right)_{2}\right), 1.81$ (s, 3H, $\mathrm{CH}_{3} \mathrm{C}=\mathrm{NAr}$ ), 1.65 (s, 3H, $\mathrm{CH}_{3} \mathrm{CNHAr}$ ), 1.19 $\left(\mathrm{d}, \mathrm{J}=7.0 \mathrm{~Hz}, 6 \mathrm{H}, \mathrm{CH}\left(\mathrm{CH}_{3}\right)_{2}\right), 1.14(\mathrm{~d}, \mathrm{~J}=7.0 \mathrm{~Hz}, 6 \mathrm{H}$, $\left.\mathrm{CH}\left(\mathrm{CH}_{3}\right)_{2}\right) .{ }^{13} \mathrm{C}$ NMR $\left(100 \mathrm{MHz}, \mathrm{C}_{6} \mathrm{D}_{6}\right) \delta$ (ppm): 164.1 $\left(\mathrm{NCCH}_{3}\right), 156.8\left(\mathrm{NCCH}_{3}\right), 156.6$ (Ar-C), 144.2 (Ar-C), 140.2 (Ar-C), 136.6 (Ar-C), 125.0 (Ar-C), 124.6 (Ar-C),

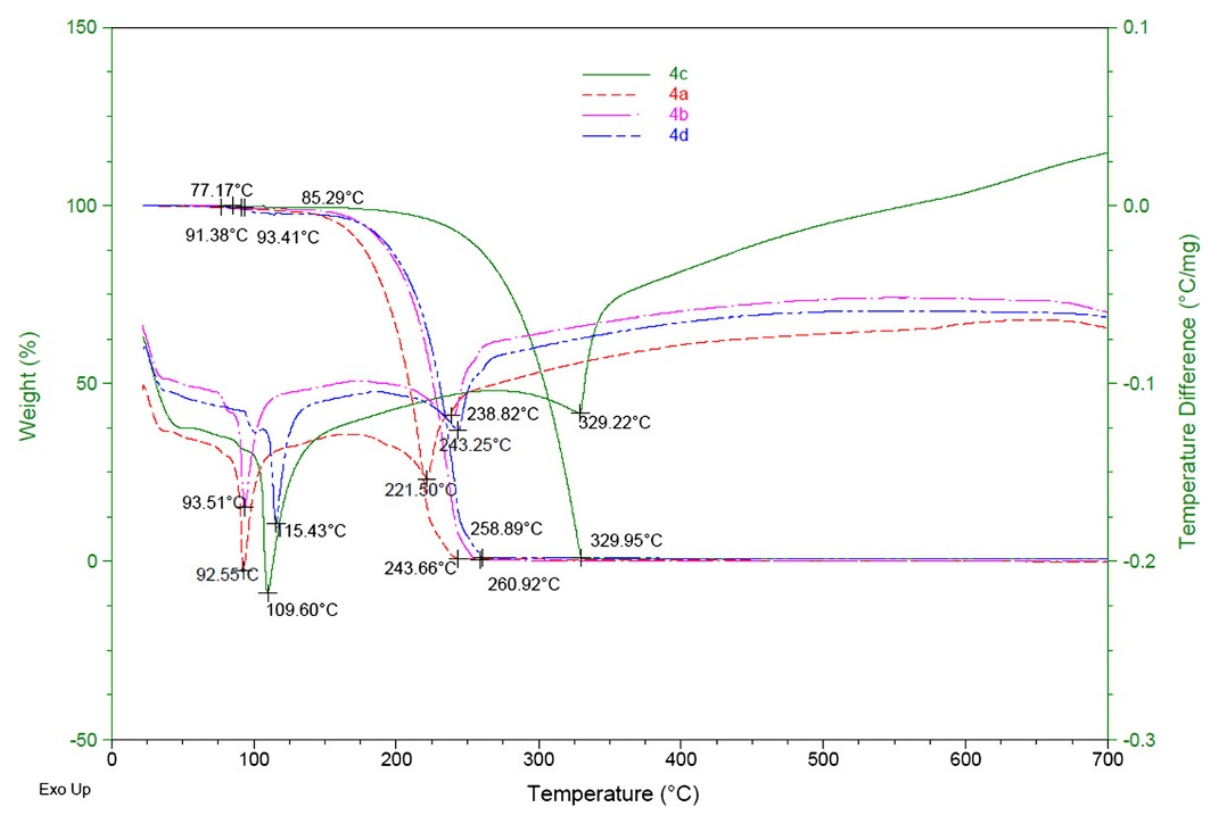

Figure 9 TGA/DTA of unsymmetrical $\beta$-diketiminates $4 a-d$. 
123.4 (Ar-C), $114.5(\mathrm{Ar}-\mathrm{C}), 95.9(\mathrm{CH}), 54.9\left(\mathrm{OCH}_{3} \mathrm{Ar}\right)$, $28.7\left(\mathrm{CH}_{3} \mathrm{C}=\mathrm{NAr}\right), 24.2\left(\mathrm{CH}\left(\mathrm{CH}_{3}\right)_{2}\right), 22.8\left(\mathrm{CH}\left(\mathrm{CH}_{3}\right)_{2}\right)$, $21.2\left(\mathrm{CH}\left(\mathrm{CH}_{3}\right)_{2}\right), 20.3\left(\mathrm{CH}_{3} \mathrm{CNHAr}\right)$. Melting point: $110.0^{\circ} \mathrm{C}$. Mass data (TOF MS EI ${ }^{+}$): Calcd for $\mathrm{C}_{24} \mathrm{H}_{32} \mathrm{~N}_{2} \mathrm{O}$ $\left[\mathrm{M}^{+}\right]$364.52, found: 364.36. Anal. Calcd for $\mathrm{C}_{24} \mathrm{H}_{32} \mathrm{~N}_{2} \mathrm{O}$ : C, 79.08; H, 8.85; N, 7.68; Found: C, 79.10; H, 8.72; N, 7.57. IR $\left(\mathrm{KBr}, \mathrm{cm}^{-1}\right)$ v: $3057(\mathrm{~m}), 2971(\mathrm{~m}), 2925(\mathrm{w})$, $2878(\mathrm{~m}), 2832(\mathrm{w}), 1631(\mathrm{~m}), 1548(\mathrm{~m}), 1520(\mathrm{~s}), 1472$ (s), $1400(\mathrm{~s}), 1320(\mathrm{~m}), 1289(\mathrm{~m}), 1260(\mathrm{w}), 1251(\mathrm{~m})$, $1233(\mathrm{w}), 1169(\mathrm{~m}), 1115(\mathrm{~m}), 930(\mathrm{w}), 795(\mathrm{~m}), 759$ (m), $753(\mathrm{w}), 740(\mathrm{~m}), 679(\mathrm{w}), 641(\mathrm{w}), 597(\mathrm{~m}), 578$ (w), $415(\mathrm{~m})$.

2-(2,6-diisopropylphenyl)amino-4-(4-methoxyphenyl) imino-2-pentene (4c). $\beta$-Diketiminate $4 \mathrm{~d}$ was synthesized by the same procedure as $4 a$. Yield $(15.10 \mathrm{~g}, 82 \%) .{ }^{1} \mathrm{H}$ NMR (500 MHz, $\left.\mathrm{C}_{6} \mathrm{D}_{6}\right) \delta(\mathrm{ppm}): 12.87$ (s, $\left.1 \mathrm{H}, \mathrm{NH}\right), 7.14-$ 7.08 (m, 3H, ArH), 7.00-6.98 (m, 2H, ArH), 6.63-6.60 (m, $2 \mathrm{H}, \mathrm{ArH}), 4.79\left(\mathrm{~s}, 1 \mathrm{H}, \mathrm{CH}=\mathrm{C}\left(\mathrm{CH}_{3}\right) \mathrm{N}\right), 3.12$ (sept, J = 6.8 $\left.\mathrm{Hz}, 2 \mathrm{H}, \mathrm{CH}\left(\mathrm{CH}_{3}\right)_{2}\right), 1.69$ (s, 3H, $\mathrm{CH}_{3} \mathrm{C}=\mathrm{NAr}$ ), 1.56 (s, 3H, $\mathrm{CH}_{3} \mathrm{CNHAr}$ ), 1.15 (d, J = 7.0 Hz, 6H, $\left.\mathrm{CH}\left(\mathrm{CH}_{3}\right)_{2}\right), 1.09$ (d, $\left.\mathrm{J}=7.0 \mathrm{~Hz}, 6 \mathrm{H}, \mathrm{CH}\left(\mathrm{CH}_{3}\right)_{2}\right) \cdot{ }^{13} \mathrm{C} \mathrm{NMR}\left(100 \mathrm{MHz}, \mathrm{C}_{6} \mathrm{D}_{6}\right) \delta$ (ppm): $161.8\left(\mathrm{NCCH}_{3}\right), 159.2\left(\mathrm{NCCH}_{3}\right), 144.9$ (Ar-C), 142.2 (Ar-C), 141.0 (Ar-C), 129.2 (Ar-C), 128.3 (Ar-C), 125.9 (Ar-C), 123.6 (Ar-C), 123.5 (Ar-C), $96.6(\mathrm{CH}), 28.7$ $\left(\mathrm{CH}_{3} \mathrm{C}=\mathrm{NAr}\right), 24.4 \quad\left(\mathrm{CH}\left(\mathrm{CH}_{3}\right)_{2}\right), 22.7 \quad\left(\mathrm{CH}\left(\mathrm{CH}_{3}\right)_{2}\right), 20.7$ $\left(\mathrm{CH}\left(\mathrm{CH}_{3}\right)_{2}\right), 20.6\left(\mathrm{CH}_{3} \mathrm{CNHAr}\right)$. Melting point: $116.0^{\circ} \mathrm{C}$. Mass data (TOF MS EI ${ }^{+}$): Calcd for $\mathrm{C}_{23} \mathrm{H}_{29} \mathrm{ClN}_{2}\left[\mathrm{M}^{+}\right]$ 368.94, found: 368.92. Anal. Calcd for $\mathrm{C}_{23} \mathrm{H}_{29} \mathrm{ClN}_{2}$ : C, 74.88; H, 7.92; Cl, 9.61; N, 7.59; Found: C, 74.89; H, 7.90; $\mathrm{Cl}, 9.58 ; \mathrm{N}, 7.55$. IR $\left(\mathrm{KBr}, \mathrm{cm}^{-1}\right)$ v: $3062(\mathrm{~s}), 2960(\mathrm{~m}), 1670$ (s), $1558(\mathrm{~m}), 1530(\mathrm{w}), 1495(\mathrm{~m}), 1450(\mathrm{~m}), 1417(\mathrm{~s}), 1325$ (m), $1271(\mathrm{w}), 1239(\mathrm{~m}), 1215(\mathrm{w}), 1182(\mathrm{~m}), 1120(\mathrm{~m})$, $1051(\mathrm{~m}), 1030(\mathrm{~m}), 930(\mathrm{w}), 864(\mathrm{~m}), 837(\mathrm{w}), 800(\mathrm{w}), 745$ $(\mathrm{m}), 677(\mathrm{w}), 635(\mathrm{w})$.

\section{Competing interests}

The authors have no competing interests.

\section{Authors' contributions}

SAP and PAM carried out the syntheses and characterization of the reported compounds. JWZ carried out the X-ray diffraction studies for all compounds reported herein. BDF conceived of the study, participated in its design and coordination, and drafted the manuscript. All authors read and approved the final manuscript.

\section{Acknowledgements}

We gratefully acknowledge funding for this work from the National Science Foundation (CHE-0911061).

\section{Author details}

'Department of Chemistry \& Science of Advanced Materials Program, Central Michigan University, Mount Pleasant, MI 48859, USA. ${ }^{2}$ Department of Chemistry, University of California, Irvine, CA 92697, USA.

Received: 18 October 2012 Accepted: 17 December 2012 Published: 31 January 2013

\section{References}

APEX2 Version 2010.9-0. (2010) Bruker AXS, Inc, Madison, WI
Bourget-Merle L, Lappert MF, Severn JR (2002) The chemistry of $\beta$-diketiminatometal complexes. Chem Rev 102:3031-3066

Cramer CJ, Tolman WB (2007) Mononuclear $\mathrm{Cu}_{-} \mathrm{O}_{2}$ complexes: geometries, spectroscopic properties, electronic structures, and reactivity. Acc Chem Res 40:601-608

Ding K, Pierpont AW, Brennessel WW, Lukat-Rodgers G, Rodgers KR, Cundari TR, Bill E, Holland PL (2009) Cobalt-dinitrogen complexes with weakened N-N bonds. J Am Chem Soc 131:9471-9472

Gong S, Ma H (2008) (2008) $\beta$-Diketiminate aluminium complexes: synthesis, characterization and ring-opening polymerization of cyclic esters. Dalton Trans 0:3345-3357

Holland PL (2008) Electronic structure and reactivity of three-coordinate iron complexes. Acc Chem Res 41:905-914

Kuhn N, Fahl J, Fuchs S, Steimann M, Henkel G, Maulitz AHZ (1999) Vinamidinchelate des aluminiums und Ggalliums. Z Anorg Allg Chem 625(12):2108-2114

McGeachin SG (1968) Synthesis and properties of some $\beta$-diketimines derived from acetylacetone, and their metal complexes. Can J Chem 46:1903-1912

Mindiola DJ (2006) Oxidatively induced abstraction reactions. A synthetic approach to low-coordinate and reactive early transition metal complexes containing metal-ligand multiple bonds. Acc Chem Res 39:813-821

Nagendran S, Roesky HW (2008) The Chemistry of aluminum(I), silicon(II), and germanium(II). Organometallics 27:457-492

Parks JE, Holm RH (1968) Synthesis, solution stereochemistry, and electron delocalization properties of bis(.beta.iminoamino)nickel(II) complexes. Inorg Chem 7:1408-1416

Pfirrmann S, Limberg C, Herwig C, Stößer R, Ziemer B (2009) A Dinuclear nickel(I) dinitrogen complex and its reduction in single-electron steps. Angew Chem Int Ed 48:3357-3361

Piers WE, Emslie DJH (2002) Non-cyclopentadienyl ancillaries in organogroup 3 metal chemistry: a fine balance in ligand design. Coord Chem Rev 233-234:131-155

Rahim M, Taylor NJ, Xin S, Collins S (1998) Synthesis and structure of acyclic bis (ketenimine) complexes of zirconium. Organometallics 17:1315-1323

Roesky HW, Singh S, Jancik V, Chandrasekhar V (2004) A Paradigm change in assembling $\mathrm{OH}$ functionalities on metal centers. Acc Chem Res 37:969-981

SAINT Version 7.68a. (2009) Bruker AXS, Madison, WI

Sheldrick GM (2008a) SADABS, Version 2008/1. Bruker AXS, Inc, Madison, WI Sheldrick GM (2008b) SHELXTL, Version 2008/4. Bruker AXS, Inc, Madison, WI Stender M, Wright RJ, Eichler BE, Prust J, Olmstead MM, Roesky HW, Power PP (2001) The synthesis and structure of lithium derivatives of the sterically encumbered $\beta$-diketiminate ligand $\left[\left\{\left(2,6-\mathrm{Pr}_{2}^{i} \mathrm{H}_{3} \mathrm{C}_{6}\right) \mathrm{N}\left(\mathrm{CH}_{3}\right) \mathrm{C}_{2} \mathrm{CH}^{-}\right.\right.$, and a modified synthesis of the aminoimine precursor. Dalton Trans 0:3465-3469

Tang LM, Duan YQ, Li XF, Li YS (2006) Syntheses, structure and ethylene polymerization behaviour of $\beta$-diiminato titanium complexes. J Organomet Chem 691:2023-2030

doi:10.1186/2193-1801-2-32

Cite this article as: Patil et al.: Syntheses, characterizations and thermal analyses of four novel unsymmetrical $\beta$-diketiminates. SpringerPlus 2013 2:32.

\section{Submit your manuscript to a SpringerOpen ${ }^{\circ}$ journal and benefit from: \\ - Convenient online submission \\ - Rigorous peer review \\ - Immediate publication on acceptance \\ - Open access: articles freely available online \\ - High visibility within the field \\ - Retaining the copyright to your article}

Submit your next manuscript at $\gg$ springeropen.com 